\title{
Strategies of Regency Adiwiyata(Green) School Management at Secondary Education Level in Sintang Regency
}

\author{
Daniel Murdani ${ }^{1}$, Abdul Hakim², Bagyo Yanuwiadi ${ }^{3}$ \\ ${ }^{1}$ Post Graduate School of Environmental and Development, Graduate, Program, Brawijaya University \\ ${ }^{2}$ Public Administration Departement, Faculty of Administration, Brawijaya University \\ ${ }^{3}$ Biology Department, Faculty of Mathematic and Science, Brawijaya University
}

\begin{abstract}
This study aims to identify the strengths, weaknesses, opportunities and threats (SWOT) and formulate coaching strategy of Adiwiyataschools in Sintang Regency. A qualitative descriptive method with IFAS and EFAS analysis technique were used. The results shows dominant strengths factor including vision, mission and objectives that are environmentally sound in Adiwiyata school team. Meanwhile dominant weakness factor involves the limited budget allocation for Adiwiyata development. The dominant factor of opportunity and threat including ability in followingcompetencies in other activities in the field of environment and mutations of school principals or teachers, respectively. Adiwiyata regency school positions based on IFAS and EFAS analysis are in quadrant II $(23,-5)$. Thus the coaching strategy includes (1) capacity building, skills and knowledge of Adiwiyata team through seminars and training funded by local government; (2) Budget allocation proportionally for supporting activities of Adiwiyata both from schools and local government that is regularly enrolled every year; (3) Vision, mission and school objectives must accommodate local wisdom of the community in protecting the environment; (4) school principal and teacher mutations should consider tracking not on a pragmatic basis. To realize the coaching strategy needs to be done continuous cooperation between the schools with various stakeholders so as to increase the predicate Adiwiyata at a higher level.
\end{abstract}

Keywords: Coaching strategy, Regency Adiwiyata, School management, Sintang Regency

\section{INTRODUCTION}

Environmental education is one of the government's efforts to overcome and suppress the rate of environmental damage. In 1996, the first cooperation was established between the two ministries, namely the Ministry of National Education and theMinistry of Environment) on environmental education in schools. The cooperation is expected to give a positive influence for the community's awareness and behaviours in managing the environment. In fact, there has not been any significant effect or change on the community's mindset in managing the environment [1]. In response, the government renewed the cooperation between the Ministry of National Education and the Ministry of Environment in 2005. As a follow up of the cooperation agreement, the Ministry of Environment issued Adiwiyata Program at the level of primary and secondary education [2].

\footnotetext{
Correspondence address: Daniel Murdani

Email : danielmurdani103@gmail.com

Address : Post Graduate School of Environmental and Developmen, Graduate Program, BrawijayaUniversity, Malang, Indonesia
}

Through the Adiwiyata program the government expects a change of mindset from all school residents in preserving the environment. The government's expectations are consistent with research conducted by Azhar,which concluded that there is a significant positive relationship between environmental knowledge with the attitude of preserving the environment [3]. In response to that, educational institutions are required to realize responsible environmental management. The form of responsibility in managing the environment in schools can be done through Adiwiyata program. Based on research conducted by Jumadil,cognitive abilities, affective and psychomotor schools that have implemented the program Adiwiyata higher when compared with the not yet Adiwiyata [4]. This can be interpreted that through the program Adiwiyata can form learners who are characterized and competitive in the learning process. Through the Adiwiyata program can initiate efforts towards sustainable development [5].

In practice Adiwiyata schools are classified into several levels namely Adiwiyata Independent, Adiwiyata National, Adiwiyata province and Adiwiyata regency. Independent and national Adiwiyata schools have greater strengths and opportunities compared to the provincial and 
regency Adiwiyata schools [6]. This phenomenon is due to Adiwiyata schools independently and nationally has a wide partnership and has been tested because it is able to pass various phases starting from the preparation phase Adiwiyata school.

At the beginning of the launch, Adiwiyata program was devoted to schools in Java. Since 2007, Adiwiyata program has been implemented thoroughly in all provinces in Indonesia. As a guide for schools and educational institutions in the implementation of Adiwiyata program, the Ministry of Environment issued a Regulation Number 5 of 2014 on Guidelines for Adiwiyata Program Implementation [7].

In order to realize regency Adiwiyata schools, the Environment Agency of SintangRegency has made various efforts in forms of counselling, mentoring and socialization. However, the reality shows that the existence of Adiwiyata schools in SintangRegency is still very minimal, especially at the level of secondary education. In particular, for the period of 2014-2015, Adiwiyata schools existing in SintangRegency have not been able to compete in the higher level Adiwiyata program of West Kalimantan Province [8]. It can be seen in Table 1 below:

Table 1. List of Regency AdiwiyataSchools in Sintang

\begin{tabular}{|c|c|c|c|}
\hline No & $\begin{array}{l}\text { School } \\
\text { Name }\end{array}$ & $\begin{array}{c}\text { Year of } \\
\text { Determination }\end{array}$ & Keterangan \\
\hline 1. & $\begin{array}{l}\text { VHS } 01 \\
\text { Sintang }\end{array}$ & 2014 & $\begin{array}{l}\text { Joining the provincial } \\
\text { level in } 2015 \text { but not yet } \\
\text { qualified }\end{array}$ \\
\hline 2. & $\begin{array}{l}\text { JHS } \\
\text { 01Tebeli } \\
\text { an }\end{array}$ & 2015 & $\begin{array}{l}\text { Joining the provincial } \\
\text { level in } 2016 \text { but not yet } \\
\text { qualified }\end{array}$ \\
\hline 3. & $\begin{array}{l}\text { JHS } 03 \\
\text { Tebelian }\end{array}$ & 2015 & $\begin{array}{l}\text { Joining the provincial } \\
\text { level in } 2016 \text { but not yet } \\
\text { qualified }\end{array}$ \\
\hline 4. & $\begin{array}{l}\text { JHS } 04 \\
\text { Sintang }\end{array}$ & 2015 & $\begin{array}{l}\text { Joining the provincial } \\
\text { level in } 2016 \text { but not yet } \\
\text { qualified }\end{array}$ \\
\hline
\end{tabular}

Source: The Environment Agency of Sintang Regency (2017)

The conditions as seen in Table 1 should be minimized because Adiwiyata program has been implemented thoroughly in Indonesia since 2007. That is, the Adiwiyata program has been running for a decade but the management and development of Adiwiyata program in Sintang Regency are still minimal so it makes the schools in Sintang difficult to compete with other schools from other regions in Indonesia. The major problem arising from the Adiwiyata school implementation in Sintang Regency is the nonoptimalschool management and the minimum coaching from the Environment Agency. To answer the problems, the researchers conducted a study related to the management and development strategies of Adiwiyata schools in Sintang Regency. The purpose of this study was (1) to analyze the attainment of the status of regency level Adiwiyata schools; (2) to identify the SWOT (strength, weakness, opportunity and threat) factor of the regency Adiwiyata schools at the secondary education level in Sintang Regency.

\section{RESEARCH METHOD}

This research used descriptive-qualitative approach. The use of descriptive-qualitative approach in this research was in the form of description of the respondents' opinions interpreted according to the questions in the questionnaire andthe interviews. The objective of this research was to identify the SWOT factor, to be then analyzed further to find out the regency Adiwiyata school position in the SWOT diagram and formulate the coaching strategiesfor the Adiwiyata schools based on the school position in the SWOT diagram. The variables being studied in this research were the policy aspect, curriculum aspect, participation aspect and infrastructureaspect. According to Sugiyonothe sample of data sources should represent the number of population [9]. Referring to that statement, the researchers used a simple random sampling technique because the population member was considered homogeneous. Members of the population in this study were all educators at 04 Sintang Junior High School and Vocational High School 01 Sintang, amounting to 243 people. Of these the samples were taken randomly by inserting each of the names into the bottle, subsequently removed as many as 15 names in sequence while shaking the bottle.

\section{Data Collection}

Data of this research were collected using the following methods: (1) Observation, conducted to observe and examine the condition of the research site; (2) Questionnaire, used to know the weight and rate of each factorof SWOT based on the respondents' opinions/ perceptions; (3) Interview, applied to find out information related to the behaviors of the schools' communities and to determine the SWOT (strength, weakness, opportunity, and threat) factors faced by the regency Adiwiyata schools [10]. To get the information the researchers interviewed the principal, Adiwiyata school team and the 
Environment Agency; (4) Documentation review, obtained by collecting information in forms of literature, reports, regulations, or other forms information deriving from official sources [9]. This research was conducted for 3 months starting from November 2017 to January 2018. During the period of time the researchers made observations in the first month as well as interviews and collect supporting documents. The next month the researchers distributed questionnaires to the respondents. In the third month to deepen the data that has been collected through the discussion for further poured in the results of research

The position of the regency Adiwiyata schools in the SWOT diagram was determined by means of weighting (a) on each factor. The total value of the overall weight of both the internal and external factors was no more than 100. Furthermore, the rating (b) of each SWOT factor was determined with the scale range of $1-4$, sequentially meaning less important (1), quite important (2), important (3), and very important (4). The next step was multiplying the weight (a) by the rating (b) on each SWOT factor to determine the total value of each internal factor (Internal Strategic Factor Analysis Summary IFAS) and external factor (External Strategic Factor Analysis Summary - EFAS). The determination of the position of the regency Adiwiyata schools in the SWOT diagram was then done with the following formula:

$$
\begin{aligned}
& X=\text { strength }(S) \text { - weakness }(W) \\
& Y=\text { opportunity }(O)-\text { threat }(T)
\end{aligned}
$$

The last step was to create strategy formulations based on the resulting quadrant position.

\section{RESULTS AND DISCUSSION}

Referring to the research data that have been analyzed in accordance with the research methods, the results and discussion are explained as follows:

1. Internal and External Factors of Regency Adiwiyata Schools

The positive internal factors of the regency Adiwiyata schools are as follows: (1) the schools have environmentally sound visions, missions and objectives, (2) the schools have a solid Adiwiyata team, (3) the environment-based curriculum is taught in an integrated manner, (4) the schools have adequate and environmentally friendly infrastructure, (5) the schools have environmentbased education curriculum and learning facilities.
These five points are the main requirements that must be owned by regency Adiwiyata schools. One point is not met then the school difficult to get predicate Adiwiyata regency [11]. By maximizing the positive internal factors, the schools have the opportunity to get the predicate of Adiwiyata at the provincial level.

On another side, the negative internal factors include as follows. (1) utilization of infrastructure facilities is notoptimal, (2) partnerships between schools, government agencies and private parties are still lacking, (3) student habituation in protecting and managing the environment are also lacking, (4) budget allocation for the development of Adiwiyata program is limited, (5) ability of educators in utilizing information technology and social media to support environmental education learning is low, (6) participation of students in environmental actions outside schools is lacking. Negative internal factors occur because school residents have not fully understood the program Adiwiyata implemented by the school. This resulted in a cleanliness facility not well maintained and budget to support Adiwiayata program is not budgeted regularly. With Adiwiyata program, the knowledge, attitude and actions of the school community should ensure the formation of environmental caring behavior [12].

As for the positive external factors, the Adiwiyata schools have opportunities to (1) obtain assistance of infrastructure facilities supporting environmental education learning, (2) cooperate with government and private parties, (3) compete in other environmental activities, (4) generate environmentally qualified, characterized and cultural graduates, (5) improve the competence of educators through seminars and training. Schools are able to take opportunities in terms of obtaining outside non-binding assistance by establishing relationships and exposing the school's vision, mission to environmental stakeholders [13]. With these relations the school gets the ease in following the competition on environmental activities and educators who have the potential to participate in training held by stakeholders, so as to realize graduates who care about the environment.

Meanwhile, the negatif external factors include: (1) principal and educator mutations threatening the sustainability of Adiwiyata programs in schools, (2) perception of school communities that Adiwiyataschool program is just for the sake of competition, (3) downgrading of Adiwiyata predicate for schools which do not 
make efforts to defend it, (4) lack of support and coaching from the Office of Education and the Environment Agency, (5) threat from nonAdiwiyata schools with higher achievement, and (6) the consideration that Adiwiyata program is unimportant and burden educators. Lack of support from the society and related agencies can threaten the development of Adiwiyata regency as in the case of hygiene facilities and infrastructure support [14]. Thus, school that better achievement the opportunity to obtain predicate Adiwiyata regency. In the change of the principal must pay attention to the track record because the principal is the highest responsible in the implementation of Adiwiyata.

The emergence of various factors is inseparable from the level of understanding and insight from each informant. According Slalahi, easy access to sources of information both from television, internet and mass media greatly affect the knowledge in utilizing the environment [15]. Informants who easily gain access to information automatically the level of knowledge related to environmental management in schools is higher. Thus, the points contained in internal factors and external factors are the result of extraction from the thinking of each informant.

\section{Weight, Rating and total value of each SWOT Factor}

The position of regency Adiwiyataschools in the SWOT diagram was needed to formulate effective strategies for the growth and development of Adiwiyata program in schools. The regency Adiwiyata school position was known from the results of the questionnaire which were then analyzed based on IFAS and EFAS analysis. The weight, rating and total value of each SWOT factor were obtained from the questionnaire based on the perceptions of educators who were the study samples. The determination of the value is important to determine the points of each SWOT factor which further determines the position of the school regency Adiwiyata in the SWOT diagram.

Based on Table 2, the main strengths of regency Adiwiyataschools are that the schools have environmentally sound visions, missions and objectives as well as have a solidAdiwiyatateam. The other strengths include having integrated environmental education curriculum and adequate infrastructure. Potentials owned must be maximized so that schools can achieve the higher-level Adiwiyataaward.

Table 2. IFAS Analysis of Strength (S) Factor

\begin{tabular}{|c|c|c|c|c|}
\hline No. & Strengths/S & $\mathbf{W}$ & $\mathbf{R}$ & $T$ \\
\hline 1. & $\begin{array}{l}\text { The schools have a solid } \\
\text { Adiwiyatateam }\end{array}$ & 21 & 4 & 84 \\
\hline 2. & $\begin{array}{lr}\text { The school have } \\
\text { environmentally } \\
\begin{array}{l}\text { visions, missions } \\
\text { objectives. }\end{array}\end{array}$ & 21 & 4 & 84 \\
\hline 3. & $\begin{array}{l}\text { The school have an adequate } \\
\text { and environmentally friendly } \\
\text { infrastructure. }\end{array}$ & 20 & 3 & 60 \\
\hline 4. & $\begin{array}{l}\text { Environment-based education } \\
\text { curriculum is taught in an } \\
\text { integrated manner. }\end{array}$ & 20 & 3 & 60 \\
\hline 5. & $\begin{array}{l}\text { The schools have an } \\
\text { environmental education } \\
\text { curriculum and learning } \\
\text { facilities. }\end{array}$ & 18 & 3 & 54 \\
\hline & Total & 100 & & 342 \\
\hline
\end{tabular}

Description: W (weight), R (rating), T (total)

Visions and mission compiled by the school is one manifestation of aspects of environmentally sound policy. Policy aspect is an important aspect in realizing Adiwiyata schools because all activities related to the program refer to vision, school mission [16]. This point is an important force that the school has. Nevertheless the vision has not been realized in the real behavior of all the citizens of the school, because there are still many students littering and bringing snacks into the classroom. Such behavior should be minimized by means of educational sanctions. For example, making artwork from garbage and fines triple the value of damaged goods.

Table 3. IFAS Analysis of Weakness (W) Factor

\begin{tabular}{|c|c|c|c|c|}
\hline No. & Weaknesses/ W & $\mathbf{W}$ & $\mathbf{R}$ & $\bar{T}$ \\
\hline 1. & $\begin{array}{l}\text { Budget allocation for Adiwiyata } \\
\text { development is still limited. }\end{array}$ & 19 & 4 & 76 \\
\hline 2. & $\begin{array}{l}\text { Student habituation in } \\
\text { environmental protection and } \\
\text { management is still lacking. }\end{array}$ & 18 & 3 & 54 \\
\hline 3. & $\begin{array}{l}\text { Participation of students in } \\
\text { environmental actions outside } \\
\text { schools is lacking. }\end{array}$ & 17 & 3 & 51 \\
\hline 4. & $\begin{array}{l}\text { Utilization of infrastructure } \\
\text { facilities is not optimal. }\end{array}$ & 16 & 3 & 48 \\
\hline 5. & $\begin{array}{l}\text { School partnership with } \\
\text { government agencies and } \\
\text { private parties are still lacking. }\end{array}$ & 15 & 3 & 45 \\
\hline 6. & $\begin{array}{l}\text { Educator' ability in utilizing } \\
\text { information technology and } \\
\text { social media to support } \\
\text { environmental education } \\
\text { learning is low. }\end{array}$ & 15 & 3 & 45 \\
\hline & Total & 100 & & 319 \\
\hline
\end{tabular}


Based on Table 3, the main weaknesses in the management of regency Adiwiyata schools are the limited budget allocation for Adiwiyata development along with the school communities' unfamiliarity or low awareness in managing and preserving the environment. Based on the manual of Adiwiyata school program, regency Adiwiyata schools must allocate $15-20 \%$ of school budget plan.

In addition to the budget, the fundamental weakness in the management of regency Adiwiyata schools is the behavior of school residents who are not yet accustomed in preserving the environment. Environmental caring behavior can be formed if it meets the requirements of the willingness of individuals to get used to behave in accordance with the rules, have a sense of environmental conditions and the exemplary figure in maintaining the environment [17]. The most important example is the principal and followed by the entire school. For that the school needs to make a slogan and a positive invitation about environmental conservation attached to the wall magazine, so that students interested and responsible make it happen. Hus can build a basic foundation in forming environmentally friendly behavior.

Based on Table 4, to get the higher-level predicate Adiwiyata, regency Adiwiyata schools have the opportunity to actively participate in other environmental competitions such as healthy school competition, environmental creativity competition and etc.

In addition, the opportunity that must be maximized is the aid of waste management facilities and infrastructure from the government and private parties. According to Meiboudi, means of waste management is one of the criteria that must be met by school-oriented green school programs [18]. For VHS 01 Sintang already has a composting machine and has been utilized, but in JHS 04 Sintang does not have the facility so that the waste generated is discharged directly to a temporary garbage disposal. Things like this should be a serious concern from the government for schools to be empowered to perform waste management in a simple way. By doing waste management the school can get additional income from the products produced.

Based on Table 5, the threats faced by regency Adiwiyataschools are related to the mutations of school principals and educators. The mutation will be a serious threat if the transferred principals or educators do not have a high commitment to the development of Adiwiyataschools. This phenomenon may lead to the downgrading of Adiwiyatapredicate and even the schools may lose the title or award as regency Adiwiyataschools.

Table 4. EFAS Analysis of Opportunity (O) Factor

\begin{tabular}{|c|c|c|c|c|}
\hline No. & Opportunities/O & $\mathbf{W}$ & $\mathbf{R}$ & $T$ \\
\hline 1. & $\begin{array}{l}\text { The schools have an } \\
\text { opportunity to compete in } \\
\text { other environmental activities. }\end{array}$ & 21 & 4 & 84 \\
\hline 2. & $\begin{array}{l}\text { The schools } \begin{array}{l}\text { have } \\
\text { environmentally qualified, } \\
\text { characterized and cultural } \\
\text { graduates. }\end{array}\end{array}$ & 20 & 3 & 60 \\
\hline 3. & $\begin{array}{l}\text { The schools have an } \\
\text { opportunity to cooperate with } \\
\text { private parties. The schools } \\
\text { have an opportunity to improve } \\
\text { the competence of educators } \\
\text { through seminars and training. }\end{array}$ & 20 & 3 & 60 \\
\hline 4. & $\begin{array}{l}\text { The schools have an } \\
\text { opportunity to get an assistance } \\
\text { of facilities and infrastructure } \\
\text { supporting environmental } \\
\text { learning. }\end{array}$ & 20 & 3 & 60 \\
\hline 5. & $\begin{array}{l}\text { The schools have an } \\
\text { opportunity to improve the } \\
\text { competence of educators } \\
\text { through seminar and training. }\end{array}$ & 19 & 3 & 57 \\
\hline & Total & 100 & & 321 \\
\hline
\end{tabular}

Description: $W$ (weight), $R$ (rating), $T$ (total)

Table5.EFAS Analysis of Threat (T) Factor

\begin{tabular}{|c|c|c|c|c|}
\hline No. & Threats/T & $\mathbf{w}$ & $\mathbf{R}$ & $\mathbf{T}$ \\
\hline 1. & $\begin{array}{l}\text { Mutations of principals and } \\
\text { educators that threaten the } \\
\text { sustainability of Adiwiyata } \\
\text { program in schools. }\end{array}$ & 19 & 4 & 76 \\
\hline 2. & $\begin{array}{l}\text { The downgrading of Adiwiyata } \\
\text { predicate for schools which do } \\
\text { not make efforts to maintain it. }\end{array}$ & 19 & 4 & 76 \\
\hline 3. & $\begin{array}{l}\text { Lack of support and coaching } \\
\text { from the Office of Education } \\
\text { and Environment Agencies. }\end{array}$ & 18 & 3 & 54 \\
\hline 4. & $\begin{array}{l}\text { Threats from non-Adiwiyata } \\
\text { schools with higer } \\
\text { achievement. }\end{array}$ & 17 & 3 & 51 \\
\hline 5. & $\begin{array}{l}\text { Perception of school } \\
\text { communities that Adiwiyata } \\
\text { school program is just for the } \\
\text { sake of competition. }\end{array}$ & 15 & 3 & 45 \\
\hline 6. & $\begin{array}{l}\text { The absence of local } \\
\text { government policies requiring } \\
\text { schools to participate in } \\
\text { Adiwiyata program. }\end{array}$ & 12 & 2 & 24 \\
\hline & Total & 100 & & 326 \\
\hline
\end{tabular}

Description: W(weight), R(rating), T(total)

The principal as the highest authority holder in the school has a big responsibility to maintain and even increase the predicate of Adiwiyata schools. In practice, the principal must implement a top 
button down-up management strategy which means not only asking students to carry out school preservation, but also able to provide an example by way of direct plunge in the effort of preserving school environment [19]. The management must be followed by all the citizens of the school so that environmental conditions can be maintained. Such a system is able to minimize the threats faced by schools in implementing the Adiwiyata program.

\section{Regency Adiwiyata School Position in SWOT Diagram}

The position of Adiwiyataschools in the SWOT diagram can be known if the value of $X$ axis and $Y$ axis has been determined. The determination of the $X$ axis is derived from the reduction between the total number of strength factor $(S)$ and the total number of weakness factor (W) orthe value of $X=S-W$. On another side, the $Y$ axis is derived from the reduction of the total number of opportunity factor (O) and the total number of threat factor $(T)$ or the value of $Y=O-T$. From the calculation of IFAS analysis, it was found that the value of $S=342$ and the value of $W=319$, then $X$ $=342-319=23$. Furthermore, from the calculation of EFAS analysis, it was obtained the value of $\mathrm{O}=321$ and the value of $\mathrm{T}=326$, then $\mathrm{Y}=$ $321-326=-5$. Based on the calculation results, it was indicated that the value of $X$ was positive and that of $Y$ was negative. Thus, the position of the regency Adiwiyata schools in Sintang Regency was in quadrant II in the SWOT analysis. In more detail, the position of the regency Adiwiyata schools in Sintang Regency in the SWOT diagram can be seen in Figure 2 as follows:

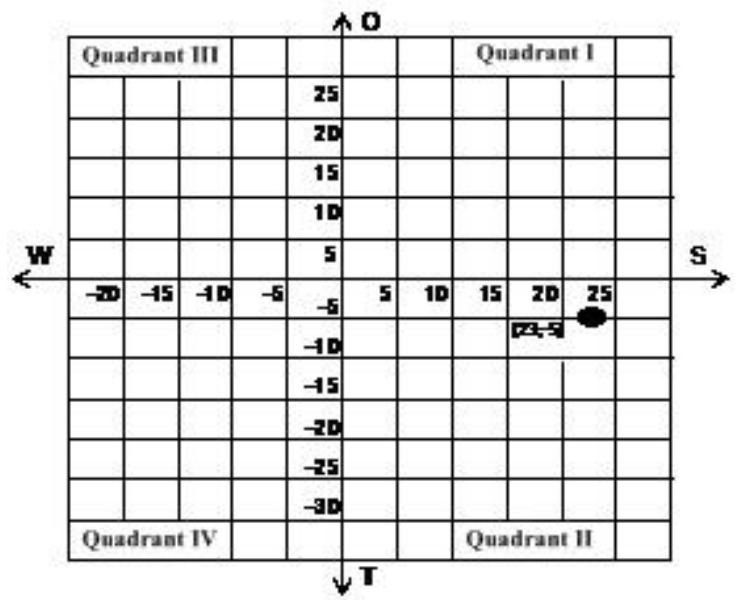

Figure 1. Position of Regency Adiwiyata Schools

Figure 1 shows that the position of the regency Adiwiyataschools in Sintang Regency was in quadrant II. The quadrant II-position indicates that the schools have the power of environmentally sound visions and missions, have a solid Adiwiyatateam and alsoenvironment-based education curriculum and learning facilities. However, at the same time, the schools also encounter threats, some of which arethat the school communities' still perceive that Adiwiyataprogram is just a competition, the support from stakeholders is still minimal, and the mutation ofprincipalsand educator mutation potentially hampers the sustainability of Adiwiyataprogram. These conditions require the schools to expand various strategies and innovation in minimizing the potential threats existing.

Based on Juliari research,Adiwiyata school regency still relies on principal policy, thus prone to be a threat in sustainability of Adiwiyata program in school [6]. To overcome these problems in mutations the principal must consider his track record and competencies. The best solution that should be done by the government is to open a school principal auction. This practice will minimize the pragmatic interest in the appointment of the principal.

Innovation that can be done by regency Adiwiyata school in order to be able to get a predicate at a higher level is to optimize good partnership with all stakeholders. Partnership is stakeholder participation in Adiwiyata program planning, stakeholder participation in implementation of Adiwiyata program, stakeholder participation in evaluation and stakeholder participation in benefit of Adiwiyata program [20]. Participation in the planning of the proposed activities that needs to be done in supporting activities such as Adiwiyata class hygiene competition activities, clean Friday movement. Participation in the implementation of a principal policy that facilitates all needs in the implementation of Adiwiyata, the committee plays an active role in raising funds. Participation in the evaluation of stakeholder appraisal of programs already designed. The assessment can be done by both internal and external school. Participation in program benefits means that the Adiwiyata school program has a direct impact on people's lives. For example, skills in managing and utilizing the environmentally, get more information in environmental protection and management efforts.

\section{Formulation of Regency Adiwiyata School Development Strategy}


Adiwiyataschool position in Sintang Regency in the SWOT diagram was in quadrant II. The position was based on the calculation of IFAS and EFAS analysis in which the data were obtained from the perceptions of educators in SMKN 01 Sintang and SMPN 04 Sintang. The regency Adiwiyataschool position in quadrant II indicates that regency Adiwiyataschools in Sintang Regency have sufficient strength to survive, but at the same time have high potential threats. The greatest threat exactly arises from the internal of the schools because the regency Adiwiyataschools still rely on the policies ruled by the principals andschools' Adiwiyatateams. This condition is potentially a high threat because the principals and educators may be transferred or promoted to a certain position at any time by the Office of Education.

Strategy of coaching by related parties (Local Government from Environment Agency and Education Office) can be done through persuasive and interactive approach. Persuasive means to approach, invitation and advices the school in a polite way. Interactive means to make a two-way communication or dialogue between the school and the local government. In addition, it is necessary to consider the conditions and needs of each school that is appreciaton as regency Adiwiyata schools so that the coaching process can run effectively and efficiently. It is intended to increase the performance of schools in developing a caring and cultured school environment, so as to achieve Adiwiyata award at a higher level.

In quadrant II, the influencing factors were strengths (S) and threats $(T)$. Therefore, the coaching strategies were derived from the formulations between the two factors. Eachof the formulationsalong with itscoaching strategiesisdescribed as follows:

(1)Strengthening the schools'Adiwiyata teams to get supports from stakeholders.

From this formulation, the coaching strategiesthat can be used are to establish intense communication with various stakeholders; improve the capacity, skills and knowledge of the schools'Adiwiyatateams through governmentprovided organizations or institutions; and prepare rational activity proposals related to environmental management.

(2) Improving environmentally friendly school facilities and infrastructure in order to maintain the title or award as Adiwiyataschools

Based on this formulation, the coaching strategies to be used are to make socialization to all the school communities about the importance of maintaining and preserving the existing facilities; impose sanctions to those who damage the cleanliness facilities; establish partnerships with stakeholders who care about the environment; and allocate proportional budget to supporting activities of Adiwiyataprogram.

(3)Having environmentally sound visions and missions rooting in all school communities so that the perception that Adiwiyata program is just for the sake of competition can be minimized.

According to this formulation, the coaching strategies that can be applied are to socialize and monitor continuously the schools' visions and missions to all the school communities; integrate the designed visions and missions with every learning process and accommodate the culture of the surrounding communities in protecting the environment.

\section{(4)Building an integrated environment-based education curriculum so that the principal and educator mutations will not threaten the sustainability of Adiwiyata program.}

Based on the formula above, the coaching strategies that can be made are to consider the track records of principals or educators before setting themutations (whether they support and care of Adiwiyataprogram or not); and to provide training and mentoring to educators in preparing environmentally-sound learning facilities.

\section{CONCLUSION}

Based on the results of research that has been conducted at regency Adiwiyataschools in Sintang regency, it can be concluded as follows:

Dominant strengths factor including vision, mission and objectives that are environmentally sound in Adiwiyata school team. Meanwhile dominant weakness factor involves the limited budget allocation for Adiwiyata development. The dominant factor of opportunity and threat including ability in followingcompetencies in other activities in the field of environment and mutations of school principals or teachers, respectively. Adiwiyata regency school positions based on IFAS and EFAS analysis are in quadrant II $(23,-5)$. Thus the coaching strategy includes (1) capacity building, skills and knowledge of Adiwiyata team through seminars and training funded by local government; (2) Budget allocation proportionally for supporting activities of Adiwiyata both from schools and local government that is regularly enrolled every year; (3) Vision, mission and school objectives must 
accommodate local wisdom of the community in protecting the environment; (4) school principal and teacher mutations should consider tracking not on a pragmatic basis.

\section{SUGGESTION}

(1) Student behaviours must reflect the attitude and character that uphold harmony with nature so as to create environmental conditions with high aesthetic value. Thus, Adiwiyataprogram must be supported by all students.

(2) Educators with high integrity, capability and competence are the main key to the establishment of cultural, characterized, and competitive civilization. Therefore, educators should be an example for learners in an effort to maintain environmental sustainability.

(3) Regency Adiwiyataschools should have optimism to achieve Adiwiyataaward at a higher level by establishing partnerships with interested stakeholders.

(4) The local government's favour towards Adiwiyataprogram will increase the quantity and quality of Adiwiyatain schools.

\section{ACKNOWLEDGEMENT}

We would like to thank the advisors who have given much valuable direction and input for the completion of this journal. Thanks are also due to the principals and Adiwiyatateams of SMKN 01 Sintangdan SMPN 04 Sintang. Lastly, we also gratefully acknowledge the help provided by the Environment Office of Sintang Regency and all staffs of Master Program of Environmental Resources Management and Development, Brawijaya University.

\section{REFERENCES}

[1]. Adam, A.F.B. 2014. Analisis Implementasi Kebijakan Kurikulum Berbasis Lingkungan Hidup Pada Program Adiwiyata Mandiri di SDN Dinoyo 2 Malang. Jurnal Kebijakan dan Pengembangan Pendidikan. 2. 2:166-173.

[2]. Panduan Adiwiyata. 2012. Kerjasama Kementerian Lingkungan Hidup dengan Kementerian Pendidikan dan Kebudayaan.

[3]. Azhar., Basyir, M.D., Alfitri. 2015. Hubungan Pegetahuan Dan Etika Lingkungan Dengan Sikap dan Perilaku Menjaga Kelestarian Lingkungan. Jurnal Ilmu Lingkungan. 13. 1:36-41.

[4]. Jumadil., Mustari, K., Hamzah, H. 2015. Penerapan Program Adiwiyata Pada Aspek Kognitif, Afektif dan Psikomotorik Tentang
Pengelolaan Lingkungan Hidup Sekolah Dasar di Kota Kendari. Jurnal sains dan teknologi. 15. 2:195-202.

[5]. Zhao, D.X., B.J. He, F.Q. Meng. 2015. The green school project: a means of speeding up sustainable development?. Journal Science Direct. 65:310-313.

[6]. Juliari, R.D.U., Amin, M., Yanuwiadi, B. 2015. Strategi Pengelolaan Sekolah Adiwiyata di Kota Batu. Jurnal Wacana. 18. 4:241-246.

[7]. Peraturan Menteri Negara LingkunganHidup Nomor 05 Tahun 2013 tentang Pedoman Pelaksanaan Program Adiwiyata.

[8]. Badan Lingkungan Hidup Kabupaten Sintang (BLH), 2017.

[9]. Sugiyono. 2014. Metode Penelitian Pendidikan: Pendekatan Kuantitatif, Kualitatifdan R\&D. Alfabeta. Bandung.

[10]. Isnaeni, Y. 2013. Implementasi Kebijakan Sekolah Peduli dan Berbudaya Lingkungan di SMP Negeri 3 Gresik. Jurnal Kebijakan dan Pengembangan Pendidikan. 1. 2:166-172.

[11]. [11].Syaikhudin, A. 2016. Menuju Sekolah Adiwiyata: Implementasi Pendidikan Lingkungan Hidup di SDN 3 Bangunsari. Jurnal of Islamic Elementary School. 1. 2:4252.

[12]. [12].Iswari, R.D., Utomo, S.W. 2017. Evaluasi Penerapan Program Adiwiyata Untuk Membentuk Perilaku Peduli Lingkungan Dikalangan Siswa (Studi Kasus SMAN 9 Tangerang Selatan dan MAN 1 Serpong). Jurnal Ilmu Lingkungan. 15. 1:35-41.

[13]. [13].Windawati, A., Setyowati, D.L. 2015. Evaluasi Program Sekolah Hijau (Green School) di SMAN 7 Purworejo Sebagai Persiapan Menuju Rintisan Sekolah Berwawasan Lingkungan dan Mitigasi Bencana (SWALIBA). Jurnal Edu Geography. 3. 7:16-22.

[14]. [14].Landriany, L. 2014. Implementasi Kebijakan Adiwiyata Dalam Upaya Mewujudkan Pendidikan Lingkungan Hidup di SMA Kota Malang. Jurnal Kebijakan dan Pengembangan Pendidikan. 2. 1:82-88.

[15]. Silalahi, E., Syarifuddin., Sudibyo, M. 2016. Faktor-faktor yang Mempengaruhi Terhadap Pengetahuan Tentang Lingkungan pada Siswa Tingkat SMP/MTSN dan SMA/MAN Adiwiyata di Kota Labuhanbatu. Jurnal pendidikan biologi. 5. 3:146-153.

[16]. Handayani, T. 2016. Evaluasi Program Adiwiyata Dalam Upaya Mewujudkan Sekolah yang Berwawasan Lingkungan di MIN Jejeran Bantul Yogyakarta. Hal. 450-460. 
Prosiding Seminar Nasional II. Universitas Muhammadiyah Malang.

[17]. Hidayati, N., Taruna.T dan Purnaweni, H. 2013. Perilaku Warga Sekolah Dalam Program Adiwiyata di SMK Negeri 02 Semarang. Hal. 149-154. Prosiding Seminar Nasional Pengelolaan Sumberdaya Alam dan Lingkungan. Universitas Diponegoro Semarang.

[18]. Meiboudi, H., A. Lahijanian, S.M. Shobeiri, S.A. Jozi, R. Azizinezhad. 2017. Development and Validation of Sustainability Criteria of Administrative Green Schools in Iran. Journal Science Direct. 197:605-609.

[19]. Hafidhoh, N., M. Sholeh. Implementasi Pelaksanaan Program Green School di SMP Negeri 01 Kudus. Jurnal Edu Geography. 3. 6:16-22.

[20]. Aulia, G. 2016. Partisipasi Stakeholder dalam Pelaksanaan Program Adiwiyata di SMPN 04 Bojonegoro. Jurnal kebijakan dan manajemen publik. 4. 3:331-341. 